Akses Online :

http://jurnal.iicet.org

Dipublikasikan oleh :

Indonesian Institute for Counseling, Education and Therapy (IICET)

Info Artikel:

Diterima: 06/29/2019

Direvisi: 08/02/2019

Dipublikasikan: 10/01/2019

\title{
Cognitive Behavior Therapy (CBT) in reducing Psychological Impacts on Children Victims of Domestic Violence
}

\author{
Afdal $^{1}$, Melsi Syawitri ${ }^{2}$, Miftahul Fikri $^{3}$ \\ ${ }^{123}$ Universitas Negeri Padang
}

\begin{abstract}
The psychological impact of violence in the household is more severe than the physical impact, including fear, anxiety, fatigue, post traumatic stress disorder, eating and sleeping disorders, and children with severe mental problems can think of suicide. This article aims to present an analysis of the psychological impact on child victims of domestic violence using the literature method and cognitive behavioral therapy approaches that can be carried out by counselors.
\end{abstract}

Keywords: Cognitive behavioral therapy, Psychological impact,Domestic violence

This is an open access article distributed under the Creative Commons Attribution License, which permits unrestricted use,
distribution, and reproduction in any medium, provided the original work is properly cited. C 2019 by author.

\section{INTRODUCTION}

Cases of violence against women and children are currently seen as quite worrying. In 2016 there were 385 cases of physical violence against women, 69 cases of sexual violence, 274 cases of domestic violence. For the West Sumatra region, Tantri Herida who is a member of the Indonesian Women's Coalition organization said that Padang had the highest number of violence cases, reaching 151 cases, including 135 physical violence, 2 psychological violence, 3 sexual violence and 11 neglect.The number of violence against children is classified as large, seen based on data in 2017 there were 558 cases, including 165 cases of physical violence and 393 cases of sexual violence(Lilyn, 2018). Violence against women and children in West Sumatra continues.From January to June 2018 the Polresta Padang Women's and Children's Services Unit has received 103 cases of violence experienced by women and children. The most reports are cases of violence experienced by women and occurred in the household (domestic violence), which is 56 cases and for violence against children totaling 47 cases (Maisany, 2018).

Children with parents who are perpetrators of violence as well as severe mental problems can think of suicide (Garcia \& Schneider, 2017). Children from cruel homes come to school with a variety of behaviors and emotions that can hinder and make it difficult for them to learn. It is often difficult for educators to find out the reasons behind behavior and learning problems experienced by children due to reasons of violence occurring in the household often kept secret from school personnel. So that violence that occurs within the scope of the household is often referred to as hidden crime because the perpetrators and victims try to keep the deeds or violence from public view which in the end it seems as if the case is like an "iceberg" whose peak is visible and the hidden part is greater than which appeared (Afdal, 2015; Soeroso, 2010). 
Counseling guidance counselor / teacher as an educator who is responsible for providing counseling services Counselors as educators who are responsible for providing counseling services and psychological handling tasks for children in school, are expected to provide a variety of models and counseling programs in the hope of reducing symptoms that disrupt feelings, emotions, comfort, and behavior of child victims of violence to be able to improve the quality of life that may be less good and impact on daily behavior (Fithrayani, 2017; Justitia, 2012).Many therapeutic models can be used to reduce or cope with the psychological impact of domestic violence (KDRT), including the model of protective behavior counseling and cognitive therapy. In this protective behavior counseling children can be trained to master their skills to reduce their vulnerability to violence from others and cognitive therapy is carried out by interfering with negative thoughts that arise due to violence in various ways (Huraera, 2007).Looking at the two models of therapy, cognitive behavior therapy (CBT) is considered suitable for children who experience domestic violence (CDR), where cognitive behavior therapy (CBT) is a combination of protective behavior counseling and cognitive therapy.Based on several studies showing CBT interventions through individual and group formats are effective in handling psychological problems in victims of domestic violence to reduce the symptoms of post-traumatic stress disorder (PTSD), depression, anxiety, positive changes in relation to emotional distress, and a significant increase in satisfaction levels life (Crespo \& Arinero, 2010; Echeburúa, Sarasua, Zubizarreta, \& de Corral, 2013; Habigzang, Aimèe Schneider, Petroli Frizzo, \& Pinto Pizarro de Freitas, 2018; Macdonald et al., 2012).

Cognitive behavior therapy (CBT) has been widely popularized and widely applied in solving mental problems (Bekirogullari, 2018). This theory combines ways of thinking and behaving based on three interrelated things namely thoughts, feelings, and behavior. The goal of therapy is to change cognitive or perception of the problem, in order to make changes in emotions and behavior and teach individuals to learn new behaviors and ways to deal with disturbing situations by learning certain skills (Beck, 2011; Fitriani, 2017).

\section{METHOD}

The method used in this study is library research. Literature research is a series of activities related to library data collection methods as a research arena (Mahmud, 2011). Literature research is carried out using a variety of literature such as books, notes, magazines, articles, and reports on the results of previous studies. The reason for using this library research method is to obtain in-depth data about the focus of research without being limited by space and time. The object of study in this study includes books, articles, notes and reports of previous research findings that are consistent with the study studied. The analysis technique used here is the content analysis technique, in which the researcher explains the counseling / counseling teacher's strategy by using cognitive behavior therapy (CBT) in reducing psychological impact on child victims of domestic violence (KDRT), with the aim of providing a description of cognitive behavior therapy (CBT) techniques that can be used to change the cognitive or perceptions of child victims of domestic violence in order to make changes in their emotions and behavior. The steps in library research include: (1) topic selection, (2) exploration of information, (3) determining research focus, (4) collecting data sources, (5) preparation of data presentation, and (6) preparing reports(Kuhlthau, 2002).

\section{RESULT \& DICUSSION}

\section{Domestic Violance}

Domestic violence is a term of violence that occurs within the scope of the household. In Indonesia, the handling related to domestic violence has been regulated by Law No. 23 of 2004 concerning the Elimination of Domestic Violence. This law defines domestic violence as any act against a person, especially against women, which results in physical, sexual, psychological, and / or neglect or suffering, including husband, wife and children (nuclear family), in-laws, in-laws, in-laws, besan (people who have family relations with the nuclear family) and domestic workers. The forms of violence can be in the form of (1) physical violence, (2) psychological violence, (3) sexual violence, forced sexual relations committed against people who live in the scope of the household, forced sexual relations against one in the scope of the household with other people for commercial purposes and / or certain purposes, and (4) neglect of household members (Undang-Undang Republik Indonesia Nomor 23 Tahun 2004 tentang Penghapusan Kekerasan dalam Rumah Tangga, 2004).In line with the above definition, Huss defines domestic violence as any violence or aggression carried out in significant interpersonal relationships, including violence between husband and wife, spouse, parents and children, adult children, and elderly parents or even siblings (Huss, 2008). Domestic violence is an act of 
controlling, coercing, threatening, violence or harassment of an intimate partner or family member regardless of gender (Ali, 2015).

\section{Factors Causing Domestic Violence}

Stress related factors, such as poverty, lack of education, lack of financial resources, levels of jealousy, excessive drinking, drug abuse and living in large families are factors that can increase the risk of domestic violence (Ely, Dulmus, \& Wodarski, 2004).In addition, the role of gender also contributes as a major cause of domestic violence, where gender bias can cause problems to become more complicated so that violence against women and girls continues to be a global epidemic such as killing, torturing, physically, psychologically, sexually and economically injuring ekonomi (Mutiso, Chessa, Chesire, \& Kemboi, 2010; Nurhayati \& Fathiyah, 2011). Other factors found as a cause of domestic violence, namely cultural and ideological factors, economic factors, settlement factors related to the lack of institutions and means to tackle and alleviate domestic violence cases, infidelity factors and differences of opinion from husband and wife who are not one more vision and mission in building a home stairs (Maisah \& Yenti, 2016; Rafikah \& Rahmawati, 2015).

\section{Psychological Impact of Domestic Violence}

The psychological impact of violence is usually more severe than the physical impact. Fear, anxiety, fatigue, post traumatic stress disorder, and eating and sleep disorders which are long reactions of violence (Maisah \& Yenti, 2016). Violence in the household not only has a negative impact on victims who experience violence, but also on children who witness violence, so children have a risk of being vulnerable to the effects of violence that occur in the household. Children who witness domestic violence are termed victims of "silence", "forgotten", and "accidentally" (Lelli, 2010).However, the emotional impact of children who witness violence is almost the same as psychological trauma of children who are victims of violence (Vidyavathi, 2015). A study conducted by Zerk et al showed that of the 60 children between the ages of one and six who were victims or witnessed violence, the majority showed behavioral problems, depression, anxiety, high levels of general difficulties and symptoms of PTSD. PTSD symptoms include hyperactivity, fear, and aggressiveness, sleep disturbance, poor concentration and significant anxiety (Zerk, Mertin, \& Proeve, 2009).

Some of the effects of violence on children are: (1) children can experience difficulty in sleeping, (2) children in the home where violence occurs in the household may indirectly receive injury or injury when household items are thrown. Older children may be injured while protecting their mothers, (3) children may experience cognitive or language problems, developmental delays, physical problems related to stress and hearing or speaking problems, (4) children experience difficulties at school, such as concentration problems, poor academic performance, difficulty interacting with peers, and more absences from school, (5) boys who witness domestic violence tend to beat their female partners as adults, whereas girls who witness violence against their mothers have a higher risk of being beaten as an adult, (6) constant anxiety and stress related disorders, (7) guilty of not being able to stop violence or because of loving the perpetrators of violence, (8) fear of abandonment, (9) social alienation and difficulty interacting with friends peers and adults, (10) low selfesteem, (11) younger children il do not understand the meaning of the violence they observe and tend to think they have made mistakes that can trigger feelings of guilt, worry and anxiety (Vidyavathi, 2015). So it can be concluded that from several studies continue to show that children affected by violence are more likely to experience higher levels of depression and anxiety, symptoms of trauma and behavioral and cognitive problems (Zerk et al., 2009).

\section{Cognitive Behavior Therapy (CBT)}

Cognitive behavior therapy (CBT) has been pioneered for the first time by Albert Ellis and Aron Beck since 1963 specifically for psychiatric patients with anxiety disorders and / or depression. CBT is a short-term therapy, commensurate with most clinical programs, structured and goal-oriented (Osman, 2008).CBT is now widely popularized and widely applied in solving mental problems (Bekirogullari, 2018).Furthermore, Antony and Swinson (inAsrori, 2015) stated that the main strategy in providing cognitive behavior therapy is to change irrational thoughts and beliefs with rational thoughts and beliefs that are healthier and more positive. CBT is based on the understanding that visible behavior is the result of thinking. With cognitive intervention, it will be able to change the way of thinking, feeling, and behaving (Islamiah, Daengsari, \& Hartiani, 2015). CBT includes beliefs related to thoughts, emotions and behavior as a system that is interconnected with one another. 
The application of this theory in CBT practice is to teach someone to learn new behaviors and ways to deal with a disturbing situation, by involving the learning of certain skills (Fitriani, 2017).

\section{Techniques Used}

The cognitive behavioral therapy (CBT) approach has many techniques taken from the behavioral approach and cognitive approach that is applied combinatively (Agustin, Saripah, \& Gustiana, 2016). Counselors or cognitive behavior therapists usually use various intervention techniques that are tailored to target behavior. According to Spiegler (2015) the techniques can be in the form of: (1) thought catching, in the form of catching thoughts with the aim of eliminating maladaptive thoughts as a cause of anxiety. The subject is accompanied to catch the wrong thoughts that strengthen feelings of anxiety and cause unexpected reactions; (2) reality testing, which is to look for evidence that supports or invalidates the assumptions of maladaptive thoughts; (3) generating alternative interpretations, namely cognitive intervention techniques that restructure the way of thinking with negative sentences into more positive or more adaptive sentences. The therapist prepares first then the subject repeats the technique himself; (4) activity schedule, which is in the form of written plans related to daily activities that must be carried out by the subject. This technique is useful for subjects who experience anxiety and depression; (5) mastery and pleasure rating, which provides a place for subjects to feel that they are able and able to enjoy the activity. Depressed subjects not only require activity, but must also be accompanied by having a feeling of being able and happy about what they are doing. According to Ladidaw et al (in Agustin et al., 2016)cognitive-behavioral counseling techniques that can be used are assertive exercises, modeling, behavioral rehearsals, meditation and relaxation, practice exercises, behavioral contracts, systematic desentization, self-management, problem solving, termination mind, cognitive restructuring, and stress management. The techniques commonly used by experts in CBT are (1) structuring irrational beliefs, (2) bibliotherapy, which accepts internal emotional conditions as interesting, (3) repeating the use of various selfstatements in role play with counselors, (4) trying to use a variety of different self-statements in real situations, (5) measuring feelings with a scale range of $0-100,(6)$ counselee learns to stop negative thoughts and turn them into positive, (7) systematic desensitization that is replacing fear and anxiety responses with relaxation responses to reduce the emotional intensity of the counselee, (8) social skills training, (9) assertiveness skill training, (10) home assignments that is to act on new behaviors and cognitive strategies between counseling sessions, (11) in vivo exposure, (12) covert conditioning which has a role in controlling behavior based on imagination, feeling and perception (McLeod, 2006).

The CBT approach given to children can be given by combining it with several approaches, including art therapy, play therapy, trauma focused-cognitive behavioral therapy and group therapy (Misurell \& Springer, 2013).According to the Cognitive-Behavior theory proposed by Aaron T. Beck, cognitive-behavior counseling requires at least 12 session sessions, including (1) assessment and diagnosis of sessions 1-2, (2) cognitive approaches session 2- 3, (3) session 3-5 formulation status, (4) session counseling focus 4-10, (5) session behavioral intervention 5-7, (6) change in core beliefs session 8-11, (7) session prevention $11-12$. Based on cultural differences and several reasons, cognitive-behavior counseling sessions in Indonesia are adjusted to be more flexible so that they can be less than 12 sessions (Oemarjoedi, 2003).

\section{CONCLUSION}

From the analysis of the literature used it can be concluded that cognitive behavior therapy (CBT) can be given in reducing the psychological impact of domestic violence on children by reasoning that, CBT involves a number of behavioral and cognitive intervention techniques by combining ways of thinking and behaving based on three interrelated things, namely the mind, feelings and behavior. CBT changes irrational thinking and beliefs with rational, positive thinking and rational beliefs. The purpose of CBT is to change perceptions or cognitive problems in order to make changes in emotions and behavior by teaching someone to learn new behaviors and ways to deal with a disturbing situation, involving learning skills.

\section{REFERENCE}

Afdal. (2015). Pemanfaatan Konseling Keluarga Eksperensial untuk Penyelesaian Kasus Kekerasan dalam Rumah Tangga. Jurnal Pendidikan Indonesia, 1(1), 76-79.

Agustin, M., Saripah, I., \& Gustiana, A. D. (2016). Efektivitas Konseling Kognitif-Perilaku dengan Teknik Latihan Asertif untuk Mengatasi Tindakan Kekerasan Pada Anak. Jurnal Ilmiah VISI PPTK PAUDNI, 
11(2), 121-129.

Ali, S. K. (2015). Domestic Violence Encountered among Kurdish Women. Journal of Educaton and Practice, $6(3), 27-34$

Asrori, A. (2015). Terapi Kognitif Perilaku untuk Mengatasi Gangguan Kecemasan Sosial. Jurnal Ilmiah Psikologi Terapan, 3(1), 89-107.

Beck, J. S. (2011). Cognitive Behavior Therapy: Basics and Beyond. Guilford Press.

Bekirogullari, Z. (2018). Cognitive Behavioural Therapy in Treating Persons with Learning Disabilities. Jurnal of Educational Science \& Psychology, VIII(2), 31-39.

Crespo, M., \& Arinero, M. (2010). Assessment of The Efficacy of A Psychological Treatment for Women Victims of Violence by Their Intimate Male Partner. The Spanish Journal of Psychology, 13(2), 849-863.

Echeburúa, E., Sarasua, B., Zubizarreta, I., \& de Corral, P. (2013). Tratamiento Psicológico De Mujeres Víctimas De Agresiones Sexuales Recientes Y No Recientes En La Vida Adulta. Psicología Conductual, 21(2), 249.

Ely, G. E., Dulmus, C. N., \& Wodarski, J. S. (2004). Domestic Violence: A Literature Review Reflecting an International Crisis. Journal Taylor \& Francis, 7, 77-91.

Fithrayani, A. (2017). Peran Konselor Sekolah dan Strategi Penanganan Kekerasan terhadap Anak. In Prosiding Seminar Nasional Bimbingan dan Konseling: Peran Profesi Bimbingan dan Konseling dalam Menanggulangi Kekerasan pada Anak (pp. 45-56). Surabaya: Adi Buana University Press.

Fitriani, A. (2017). Cognitive Behavior Religious Therapy untuk Menurunkan Tingkat Episode Depresi pada Pasien Depresi dengan Gejala Psikotik. Jurnal Psikologi Proyeksi, 12(1), 77-87.

Garcia, C. B., \& Schneider, L. (2017). Systemic Approach in Latino Families Surviving Domestic Violence in the United States of America. Journal of Educational Psychology, 5(2), 299-319. https://doi.org/http://dx.doi.org/10.20511/pyr2017.v5n2.164

Habigzang, L. F., Aimèe Schneider, J., Petroli Frizzo, R., \& Pinto Pizarro de Freitas, C. (2018). Evaluation of the Impact of a Cognitive-Behavioral Intervention for Women in Domestic Violence Situations in Brazil. Universitas Psychologica, 17(3), 52-62.

Huraera, A. (2007). Child Abuse: Kekerasan Terhadap Anak. Bandung: Nuansa.

Huss, M. T. (2008). Forensic psychology. John Wiley \& Sons.

Islamiah, N., Daengsari, D. P., \& Hartiani, F. (2015). Cognitive Behavior Therapy untuk Meningkatkan SelfEsteem Pada Anak Usia Sekolah. Jurnal Ilmu Keluarga Dan Konsumen, 8(3), 142-152.

Justitia, D. (2012). Model Layanan Bimbingan dan Konseling untuk Menangani Dampak Trauma, 26, $138-145$.

Kuhlthau, C. C. (2002). Teaching The Library Research. USA: Scarecrow Press Inc.

Lelli, C. M. (2010). Incorporating Domestic Violence Awareness Through An Undergraduate Reading Course Focused On Children's Literature.

Lilyn, Y. (2018, October 10). Ratusan Aktivis Perempuan Desak DPRD Sumbar, Sahkan RUU Penghapusan Kekerasa Seksual. Top Satu. Retrieved from https://www.topsatu.com/ratusan-aktivis-perempuan-desakdprd-sumbar-sahkan-ruu-penghapusan-kekerasa-seksual/

Macdonald, G., Higgins, J. P. T., Ramchandani, P., Valentine, J. C., Bronger, L. P., Klein, P., ... Richardson, G. (2012). Cognitive-behavioural Interventions for Children who have been Sexually Abused. Cochrane Database of Systematic Reviews, (5).

Mahmud. (2011). Metode Penelitian Pendidikan. Bandung: Pustaka Setia.

Maisah, \& Yenti. (2016). Dampak Psikologis Korban Kekerasan Dalam Rumah Tangga di Kota Jambi. Jurnal Esemsia, 17(2), 265-277.

Maisany, E. (2018, September 13). Stop Kekerasan terhadap Perempuan dan Anak. Padang Ekspress. Retrieved from https://padek.co/koran/padangekspres.co.id/read/detail/111942/Stop-Kekerasan-terhadapPerempuan-dan-Anak

McLeod, J. (2006). Pengantar Konseling: Teori dan Studi Kasus. Jakarta: Kencana.

Misurell, J. R., \& Springer, C. (2013). Developing Culturally Responsive Evidence-Based Practice: A GameBased Group Therapy Program for Child Sexual Abuse (CSA). Journal of Child and Family Studies, 22(1), 137-149.

Mutiso, M. M., Chessa, S. R., Chesire, M. A., \& Kemboi, L. (2010). Factors Leading to Domestic Violence in Low-Income Residential Areas in Kenya: A Case Study of Low-income Residential Areas in Kisumu City. Journal of Emerging Trends in Educational Research and Policy Studies (JETERAPS), 1(2), 65-75.

Nurhayati, S. S. S. R., \& Fathiyah, K. N. (2011). Model Pemberdayaan Masyarakat untuk Mencegah Kekerasan dalam Rumah Tangga. Jurnal Penelitian Humaniora, 16(1), 1-21.

Oemarjoedi, A. K. (2003). Pendekatan Cognitive Behavior dalam Psikoterapi. Jakarta: Kreativ Media.

Osman, A. Z. (2008). Keefektifan Cognitive Behavior Therapy (CBT) untuk Menurunkan Tingkat Kecemasan 
114

dan Meningkatkan Kualitas Hidup Tahanan / Narapidana Penyalahguna Napza di Rumah Tahanan Kelas I Surakarta.

Rafikah, \& Rahmawati. (2015). Peranan Pusat Pelayanan Terpadu Pemberdayaan Perempuan dan Anak (P2TP2A) dalam Menghapuskan Kekerasan dalam Rumah Tangga (KDRT) di Kota Bukittinggi. Journal of Islamic \& Social Studies, 1(2), 173-186.

Soeroso, M. H. (2010). Kekerasan Dalam Rumah Tangga dalam Perspektif Yuridis-Viktimologis. Jakarta: Sinar Grafika.

Spiegler, M. D. (2015). Contemporary Behavior Therapy (6th ed.). Cengage Learning.

Undang-Undang Republik Indonesia Nomor 23 Tahun 2004 tentang Penghapusan Kekerasan dalam Rumah Tangga (2004).

Vidyavathi, G. (2015). Consequences and Cost of Domestic Violence. International Journal Of Multidisciplinary Advanced Reasearch Trends, 2(2), 73-78.

Zerk, D. M., Mertin, P. G., \& Proeve, M. (2009). Domestic Violence and Maternal Reports of Young Children's Functioning. Journal of Family Violence, 24(7), 423-432. 